\title{
Flexural Strength of Pure Ti, Ni-Cr and Co-Cr Alloys Submitted to Nd:YAG Laser or TIG Welding
}

\author{
Rick ROCHA ${ }^{1}$ \\ Antônio Luiz Barbosa PINHEIRO ${ }^{1,2}$ \\ Antonio Balbin VILLAVERDE \\ ${ }^{1}$ Faculty of Health Sciences, Institute of Research and Development (IP\&D), \\ University of Vale do Paraíba, São José dos Campos, SP, Brazil \\ ${ }^{2}$ Laser Center, Faculty of Dentistry, Federal University of Bahia (UFBA), Salvador, BA, Brazil
}

\begin{abstract}
Welding of metals and alloys is important to Dentistry for fabrication of dental prostheses. Several methods of soldering metals and alloys are currently used. The purpose of this study was to assess, using the flexural strength testing, the efficacy of two processes Nd:YAG laser and TIG (tungsten inert gas) for welding of pure Ti, Co-Cr and $\mathrm{Ni}-\mathrm{Cr}$ alloys. Sixty cylindrical specimens were prepared (20 of each material), bisected and welded using different techniques. Four groups were formed ( $\mathrm{n}=15)$. I: Nd:YAG laser welding; IINd:YAG laser welding using a filling material; III- TIG welding and IV (control): no welding (intact specimens). The specimens were tested in flexural strength and the results were analyzed statistically by one-way ANOVA. There was significant differences ( $<<0.001)$ among the non-welded materials, the Co-Cr alloy being the most resistant to deflection. Comparing the welding processes, significant differences $(\mathrm{p}<0.001)$ where found between TIG and laser welding and also between laser alone and laser plus filling material. In conclusion, TIG welding yielded higher flexural strength means than Nd:YAG laser welding for the tested Ti, Co-Cr and Ni-Cr alloys.
\end{abstract}

Key Words: laser welding, tungsten inert gas welding, Nd:YAG laser, dental prosthesis, dentistry.

\section{INTRODUCTION}

Welding is a widely used process during fabrication of dental prostheses. Several techniques are currently in use and each of them has benefits and disadvantages. The choice for a welding method will depend on whether the technique produces enough heat to join the materials without distortion and preserves their properties, whether the materials to be welded are similar or different metals/alloys, and which would be the procedural costs (1).

The use of titanium on several medical and dental applications, mainly dental implants, has increased greatly over the last 10 years, due its biocompatibility, resistance to corrosion, and mechanical and physical properties (2). There is a trend towards the replacement of the alloys currently used for fabrication of dental prostheses by titanium, as it has lower specific density, higher ductility and lower thermal conductivity than $\mathrm{Co}-\mathrm{Cr}$ and Ni-Cr alloys (2).

It has been shown that laser welding results in less distortion in comparison to conventional methods. An advantage of laser welding is the possibility of carrying out the procedure directly on the plaster model avoiding the several steps that are needed when conventional techniques are used $(3,4)$. Laser welding is a low-cost and safe process and may be performed close to plastics, resins or ceramics parts of a dental prosthesis without risks of damage because heating does not spread too far away from the welded site. This technique requires a small gas protected zone to reduce irregularities and internal defects within the welding site that could result in poor weld resistance.

TIG (tungsten inert gas) welding is carried out

Correspondence: Prof. Dr. Antônio L. B. Pinheiro, IP\&D, Universidade do Vale do Paraíba, Av Shishima Hifumi 2911, Urbanova, 12244000 São José dos Campos, SP, Brasil. Tel: +55-12-3947-1138. Fax: +55-12-3947-1149. e-mail: pinheiro@univap.br; abv@univap.br 
under an argon environment and is used with a union material that is placed around the welding site (5). During this process, heating is highly concentrated and disturbances of thermal origin and deformation are minimized $(6,7)$.

The purpose of this study was to assess, using the flexural strength testing, the efficacy of two processes (Nd:YAG laser and TIG) for welding of pure Ti, Co-Cr and Ni-Cr alloys.

\section{MATERIAL AND METHODS}

Sixty cylindrical specimens (3 $\mathrm{mm}$ in diameter; $25 \mathrm{~mm}$ in length) were fabricated from pure titanium (Rematitan M TI-31g; Dentaurum, Pforzheim, Germany), a Ni-Cr alloy (Ni 61\%, Cr 26\%, Mo 11\%, Si $1.0 \%$ and $1 \%$ Fe, Co and Ce; Remanium, Dentaurum) and a Co-Cr alloy (Co 64.8\%, Cr 29\% and Mo 4.5\%; Remanium GM380; Dentaurum). Twenty specimens of each material were prepared.

The cylinders were randomly assigned to four groups of 15 specimens each (5 cylinders of each material per group), bisected transversally and welded (except for the control group that remained intact). Description of groups is given bellow:

Group I: the sectioned specimens were welded using a Nd:YAG laser device (model DL2002S, Dentaurum). The following parameter settings were used: $1064 \mathrm{~nm}$ wavelength, $10 \mathrm{~ms}$ repetition rate and $6.58 \mathrm{~kJ} / \mathrm{cm}^{2}$ energy density (for Ti specimens) and 12 ms repetition rate and $7.49 \mathrm{~kJ} / \mathrm{cm}^{2}$ energy density for Ni-Cr and Co-Cralloys. Group II: Nd:YAG laser welding using a filling material (0.4-mm-diameter titanium wire (Welding Dentaurum; Dentaurum). The laser parameter settings for $\mathrm{Ti}, \mathrm{Ni}-\mathrm{Cr}$ and $\mathrm{Co}-\mathrm{Cr}$ alloys were: $8 \mathrm{~ms}$ repetition rate and $2.3 \mathrm{~kJ} / \mathrm{cm}^{2}$ energy density. Group III: the specimens were welded using the TIG method with Syncrowave 300S system (Miller Electric Mfg. Co., Appleton, WI, USA). The TIG parameter settings were: $10 \mathrm{~V}, 15-20 \mathrm{~A}$ and $12 \mathrm{~s}$ working time. Group IV (control): non-sectioned, non-welded specimens.

The specimens were radiographed to assess the presence of defects caused by the casting or welding processes. X-ray tests were conducted at the Industrial Foment and Coordination Institute of the Brazilian Aerospace Technical Center (CTA) (São José dos Campos, SP, Brazil). When bubbles were detected, radiographs were taken at different angulations $\left(0^{\circ}\right.$ and $90^{\circ}$ ) to determine bubble location. Specimens that presented bubbles due to the casting process or defects caused by the welding that could alter their structure were discarded and replaced.

The cylinders were submitted to flexural strength test in an Instron machine (Instron Co., Canton, MA, USA) at a crosshead speed of $0.5 \mathrm{~mm} / \mathrm{min}$ and a load cell of $500 \mathrm{~kg}$ applied on the welded interface (or at the middle point of the rod for non-welded specimens). The specimens were fixed to two supports separated by a 20-mm distance. Loading was applied up to plastic deformation of the specimen or its rupture (whatever occurred first). Data were analyzed statistically by oneway ANOVA using Instat statistical software package (GraphPad Software, Inc., San Diego, CA, USA).

\section{RESULTS}

Flexural strength means for each group are given in Table 1. Figure 1 shows data displayed by material. TIG welding increased the flexural strength of $\mathrm{Ti}$, Co-Cr, Ni-Cr as the welded cylinders presented higher flexural strength than non-weld cylinders. The highest means were observed for Co-Cr weld by TIG

Table 1. Flexural strength means (in $\mathrm{MPa}$ ) and $\pm \mathrm{SD}$ for pure $\mathrm{Ti}$, $\mathrm{Ni}-\mathrm{Cr}$ and $\mathrm{Co}-\mathrm{Cr}$ specimens (non-welded and welded groups).

\begin{tabular}{lc} 
Welding technique & Flexural bond stre \\
\hline $\mathrm{Nd}$ :YAG laser (Group I) & \\
$\mathrm{Ti}$ & $1069 \pm 187$ \\
$\mathrm{Ni}-\mathrm{Cr}$ & $460 \pm 276$ \\
$\mathrm{Co}-\mathrm{Cr}$ & $464 \pm 70$
\end{tabular}

Nd:YAG laser + filling

material (Group II)

$\mathrm{Ti}$

$1224 \pm 27$

$\mathrm{Ni}-\mathrm{Cr}$

$1370 \pm 81$

$\mathrm{Co}-\mathrm{Cr}$

$1492 \pm 197$

TIG (Group III)

$\mathrm{Ti}$

$1609 \pm 90$

$\mathrm{Ni}-\mathrm{Cr} 1$

$1759 \pm 559$

$\mathrm{Co}-\mathrm{Cr}$

$2665 \pm 281$

No welding (Group IV)

$\mathrm{Ti}$

$1302 \pm 27$

$\mathrm{Ni}-\mathrm{Cr}$

$1488 \pm 176$

Co-Cr

$2654 \pm 64$ 
$(2665 \pm 281 \mathrm{MPa})$ and non-weld Co-Cr $(2654 \pm$ $64 \mathrm{MPa}$ ). The intact Ti cylinders showed lower flexural strength (1302 $\pm 27 \mathrm{MPa})$.

Laser welding of Co-Cr and $\mathrm{Ni}-\mathrm{Cr}$ alloys resulted in low flexural strength ( $464 \pm 70 \mathrm{MPa} ; 460 \pm 276 \mathrm{MPa})$. The use of a filling material with laser welding significantly increased the flexural strength, particularly for the alloys. Laser welding yielded the lowest means for all three materials.

There was significant differences among the non-welded materials ( $\mathrm{p}<0.001)$, the $\mathrm{Co}-\mathrm{Cr}$ alloy being the most resistant to deflection. There were significant differences between non-welded $\mathrm{Ti}$ and $\mathrm{Ti}$ welded by TIG $(p<0.01)$ and between the latter and laser-welded Ti cylinders $(\mathrm{p}<0.05)$. Laser welding in combination with the filling material (titanium wire) also resulted in significant differences among the materials $(\mathrm{p}<0.001)$. For the Co-Cr alloy, there was significant difference $(\mathrm{p}<$ 0.001 ) between non-welded and laser-welded specimens, as well as between cylinders welded with laser alone and laser associated with a filling material. For the Ni-Cr alloy, non-welded and laser-welded groups also differed statistically $(\mathrm{p}<0.001)$.

When the different welding processes were compared, significant differences were observed between TIG welding and Nd:YAG laser $(\mathrm{p}<0.001)$ and between laser welding and laser welding plus filling material $(p<0.001)$. The use of the filling material showed only significant difference on the flexural strength of Co-Cr alloy ( $\mathrm{p}<0.001)$. Regarding TIG welding, CoCr differed statistically from $\mathrm{Ti}$ and Ni-Cr alloys $(p<0.001)$. Regarding laser welding, Ti differed statistically from Co-Cr and Ni-Cr alloys $(p<0.001)$.

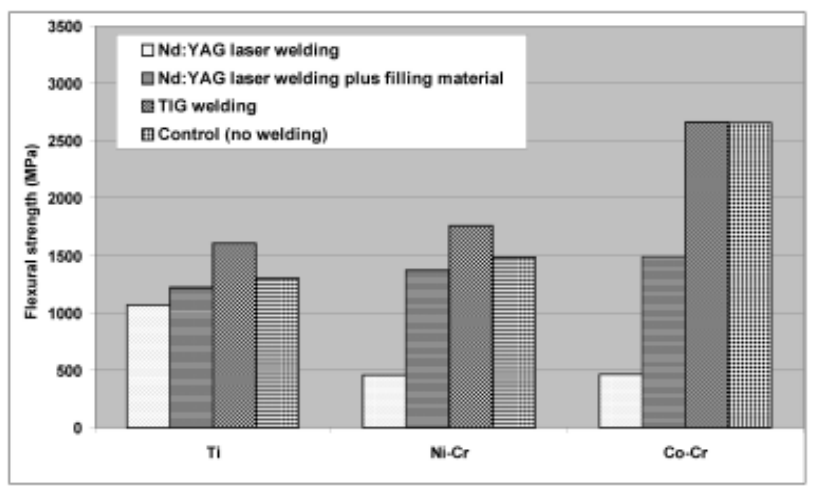

Figure 1. Flexural strength of the specimens samples displayed separated by material.

\section{DISCUSSION}

In this study, all welding procedures were carried out in an argon environment to prevent the oxidation process that may lead to a weak union (1,6-12).

The use of the TIG system led to better results compared to the other methods used in this study (Nd:YAG laser welding with and without filling material). This result may be due to the use of a powerful heat source (TIG) that was able to increase the size of the welded site without reducing the diameter of the welded transverse area (5). The main disadvantage of the use of the TIG system is its high equipment, material and manpower costs (6). Despite the better flexural strength results of the TIG system, laser welding is the most recommended technique because it is quick, precise and easy to be carried out (13). Additionally, laser welding also leads to little distortion (14) and may be used for repairing different types of prostheses even when the weld point is close to resins or ceramics. This is possible because the periphery of the weld site remains at lower temperatures $(11,15)$.

The outcomes of this study showed that titanium, Co-Cr and Ni-Cr specimens submitted to TIG welding presented higher flexural strength than non-welded specimens. Co-Cr specimens showed the highest flexural strength and titanium specimens showed the flexural strength lowest. TIG welding yielded better results than Nd:YAG laser welding associated or not to the use of filling material.

\section{RESUMO}

O processo de soldagem de metais e ligas é importante para a Odontologia para fabricação de próteses dentárias. Existem atualmente diversos métodos utilizados na soldagem de metais e ligas. O objetivo deste trabalho foi avaliar a solda do Titânio e ligas de Ni-Cr e Co-Cr usando o sistema TIG e o laser Nd:YAG utilizando o teste de resistência à flexão. Sessenta corpos-deprova cilíndricos foram confeccionados (20 de cada material), seccionados ao meio e soldados por TIG ou por laser de Nd:YAG, com e sem um material da preenchimento. Quaro grupos foram formados $(n=15)$. I: soldagem a laser de Nd:YAG; II: soldagem à laser usando um material de preenchimento; III: soldagem com TIG; IV (controle): sem soldagem (corpos-de-prova intactos) As amostras foram submetidas a ensaios de flexão e os resultados analisados pela ANOVA a um critério. Houve diferença estatisticamente significante entre o metal e as ligas íntegras $(\mathrm{p}<0.001)$, sendo a liga do Co-Cr o mais resistente à deflexão. Ao se comparar os diferentes processos de soldagem, diferença estatisticamente significante $(\mathrm{p}<0.001)$ foi encontrada entre a solda TIG e o laser de Nd:YAG e entre este e o laser mais o 
material de preenchimento. Conclui-se que a soldagem com TIG apresentou melhores resultados que a soldagem com o laser de Nd:YAG para os três materiais testados.

\section{ACKNOWLEDGEMENTS}

The authors acknowledge Mr. Dalcy Roberto dos Santos and Mr. Rodolfo de Queiroz Padilha (on behalf of AMR/IAE/CTA), for their orientation on the mechanical assays. The authors are also grateful to the Laboratorio Vaiaze, in special to Mr. Romulo Gavazzi Neto and Mr. Antonio Vaiano Junior, for their valuable assistance for development of this study.

\section{REFERENCES}

1. Brandi, SD. Solidificação da poça de fusão. In: Soldagem: Processos e Metalurgia. Wainer E, Brandi SD, Homem De Mello FD. (Editors). São Paulo: Edgard Blucher; 1992. p. 371-386.

2. Wang RR; Fenton A. Titanium for prosthodontic applications: A review of literature. Quintessence Int 1996;27:401-408.

3. Preston JD, Reisbick MH. Laser fusion of selected dental casting alloys. J Dent Res 1975;54:232-238.

4. Van Benthem H. Voitele des laserschweiBens im Vergleich zu Konventionellen Fügeverfahren. Quintessenz Zahntech 1991;17:1178-1193.
5. Okumura T, Taniguchi C. Engenharia de soldagem e aplicações. São Paulo: LTC; 1982.

6. Perini AL. Soldagem em atmosfera gasosa TIG, MIG e MAG. 17th ed. São Paulo: Associação Brasileira de Metais; 1981.

7. Nippes EF. Metals Handbook. 9th ed. v.6: Welding, brazing and soldering. Materials Park, OH: ASM International; 1983.

8. Apotheker H, Nishimura I, Seerattan C. Laser-welded vs soldered nonprecious alloy dental bridges: a comparative study. Lasers Surg Med 1984;4:207-213.

9. Hero H, Syverud M, Waarli M. Mold filling and porosity castings of titanium. J Dent Mater 1993;3:15-18.

10. Yamagishi T, Ito M, Fugimura Y. Mechanical properties of laser welds of titanium in dentistry by pulsed Nd:YAG laser apparatus. J Prost Dent 1993;70:264-273.

11. Tambasco J, Anthony T, Sandven O. Laser welding in the dental laboratory: an alternative to soldering. J Dent Technol 1996;13:23-31.

12. Dinato JC. Chemical, microstructural and hardness analysis of laser welded for implant prostheses alloys. In: Annual Meeting Biotechnology Revolutions in Implant Reconstruction, vol 14. Palm Springs: Academy of Osseointegration; 1999.

13. Gordon TE, Smith DL. Laser welding of prosthesis - an initial report. J Prosthet Dent 1970;24:472-476.

14. Dobberstein H. SchweiBen von kobalt-chrom-, nickel-chromand silber-palladium-legierungen mittles festkörperlaser. Zahn Mund Kwferheilkd 1990;78:259-261.

15. Frentzen M, Koort HJ. Lasertechnit in der zahnheilkunde. DST. Zahnarzth 1991;46:443-452.

Accepted May 23, 2005 